\title{
Implementation and Evaluation of User Experience on Mobile Augmented Reality Technology-Based Brochure Applications
}

\author{
Aulia Akhrian Syahidi*', Arifin Noor Asyikin ${ }^{2}$, Rahimatus Sania ${ }^{3}$, Subandi ${ }^{4}$ \\ 1,2,3,4 Interactive Media, Game, and Mobile Technologies Research Group, \\ Augmented Reality and Virtual Reality Laboratory, Politeknik Negeri Banjarmasin \\ email: aakhriansyahidi@poliban.ac.id*1, arifin@poliban.ac.id ${ }^{2}$, \\ rahimatussania.99@gmail.com ${ }^{3}$, subandi@poliban.ac.id ${ }^{4}$
}

(Received: 2 Mei 2021 / Accepted: 27 Juni 2021/ Published Online: 20 Desember 2021)

\begin{abstract}
Along with the spread of the COVID-19 virus which has an impact on new student admissions at various universities in Indonesia. This impact was also felt at the Politeknik Negeri Banjarmasin (POLIBAN) with the decline in the number of registrants and the public's interest in continuing higher education. So, we need a promotion that is not monotonous and must be innovative. Various kinds of technology have been created to support and facilitate all activities in various fields, one of which is in the field of promotional media. Promotion is very important for a university to offer or show the facilities and infrastructure contained in the university and show its quality. The purpose of this study is to implement mobile augmented reality technology as a POLIBAN promotional media solution and evaluate the user experience of the application. The research method used is the Extreme Programming (XP) development method and a technique for evaluating user experience using the User Experience Questionnaire (UEQ). The results of the research conducted based on the results of the implementation stated that functionally all the features offered by the application can function properly and the results of the evaluation of user experience as a non-functional assessment of 50 respondents with an average value of 2.87 with an excellent predicate.
\end{abstract}

Keywords: Extreme Programming Development Method, Mobile Augmented Reality, University Promotional Media, User Experience Evaluation

\section{INTRODUCTION}

New Student Admission is routine activity at universities every year. All universities in Indonesia have their way of attracting prospective students to enter their respective universities. New problems arise when the spread of COVID-19 Virus. The spread of the COVID-19 virus has had a huge impact, not only on the economic sector but also on the education sector. According to MedIndo (2020) which released a statement that the COVID-19 Virus Pandemic had an effect on the field of higher education. The influence of COVID-19 affects the teaching and learning process, new student admissions, tuition fees, and others. Based on research from Afendi, Gustia, \& Maleha (2021) which states that there has been a quite drastic decline in the number of new student registrants at a number of universities such as Universitas Indo Global Mandiri, Universitas Budi Luhur, Universitas Pancasila, and other universities.

One of the causes is the decline in an economic capacity and people's purchasing power so that the ability to continue to higher education is low. According to Prodjo in research from Indrawati (2020) which states that for universities, as a result of the many layoffs, it will affect a decrease in family income sources, which can reduce people's interest in not continuing or delaying continuing higher education, thus having an impact on reducing the number prospective new students. The university also seeks strategies to increase the interest of prospective new students to register and be able to continue to college. 
Politeknik Negeri Banjarmasin (POLIBAN) is a vocational college that has launched many promotional methods to attract prospective students, including promotion using brochures. Brochures are certainly not something that is foreign to us and can be found on many occasions in everyday life. Brochures generally have the function of providing information on products or services offered to potential customers. The brochures that are most often found are usually brochures regarding the promotion of places to eat, course places, tourist attractions, schools, colleges, and so on. Brochures are needed to be a means of promotion. According to Suryadi (2011) states that promotion is very important for an agency to offer or show facilities and infrastructure. In POLIBAN itself, this brochure facility is considered too monotonous for the new student admissions committee to carry out. In addition to the problem of brochures which tend to be monotonous. In this case, following the results of research that has been obtained from the POLIBAN new student admissions committee, it is stated that there has been a decline in student enrolment interest in POLIBAN since the last two years and the addition of COVID-19 virus cases is still increasing.

Based on these things, a good idea was born to recommend the latest technology to be able to provide solutions in solving the problems at hand. The latest technology that is very trendy is Augmented Reality (AR) technology which can be applied using a mobile application, so that brochures can display information in the form of modelling of buildings in POLIBAN in 3-dimensional (3D) form along with other supporting information as a means of introducing the campus, besides that, it is hoped that it can attract greater interest for prospective new students.

AR systems have the characteristics of combining real and virtual environments, running in real-time, and integrating 3D models (Azuma, 1997). AR technology is an alternative method that provides an overlay of virtual objects into a real environment (Kato \& Billinghurst, 1999). Meanwhile, according to Syahidi, Tolle, Supianto, \& Arai (2019), AR is a merger between the digital world and the real world in real-time, AR technology uses the real-world environment at that time then adds new information with the help of computers, webcams, androids, and special glasses such as Google Glass. AR is a combination of digital objects in 2D and 3D with the real world. According to Subandi, Joniriadi, Syahidi, \& Mohamed (2020), the term Mobile Augmented Reality refers to an AR application that can be installed and only focuses on the mobile device/smartphone when the AR is used.

Several studies have recommended AR technology as a promotional media and can have a good effect on the specialization of prospective new students in a university, namely research from Hermawan \& Hariadi (2015) builds an AR-based campus brochure application as a promotional and information media, the results obtained from the study show that users can see the AR brochure in detail and the environment on the brochure will also feel more alive with supporting animations such as buildings, trees, and so forth. Research by Nadira, Sujaini, \& Pratiwi (2016) states that using brochures alone has limitations so that AR is needed as a media for visualizing and enriching information in the Informatics Engineering Study Program at the University of Tanjungpura, the results of the study stated that it could help prospective new students to get information that had not been found in the brochure. Furthermore, research from Rachmanto \& Noval (2018) which developed the AR-based Nurtanio University brochure as a means for promotional media and is expected to add a variety of attractive and interactive promotional media, the results of the study state that with the AR technology implemented in promotional brochures is a new way and can attract new prospective students and be able to introduce universities.

Based on several studies of this kind, the implementation of AR technology can attract prospective new students and as a promising latest promotional media. The reason for choosing AR technology as a media to enrich interactions in promotional brochures is that there is an interactive element, rich in information, and can introduce universities. However, from several 
similar studies, it is necessary to improve the user interface, multi-interaction elements, and present more detailed and interesting information.

The research proposed now is to recommend the implementation of Mobile Augmented Reality Technology as a promotional media solution that is not monotonous and is expected to attract prospective new students. User experience evaluation is also carried out to find out the experience when using the application and explore suggestions for future improvements.

\section{METHOD}

The software development method used in application development in this study is the type of Extreme Programming (XP). According to Pressman (2010) states that XP is one of the existing models in Agile Software Development. XP uses an object-oriented approach and is suitable for mobile-based applications. The stages carried out in the XP development method can be seen in figure 1 .

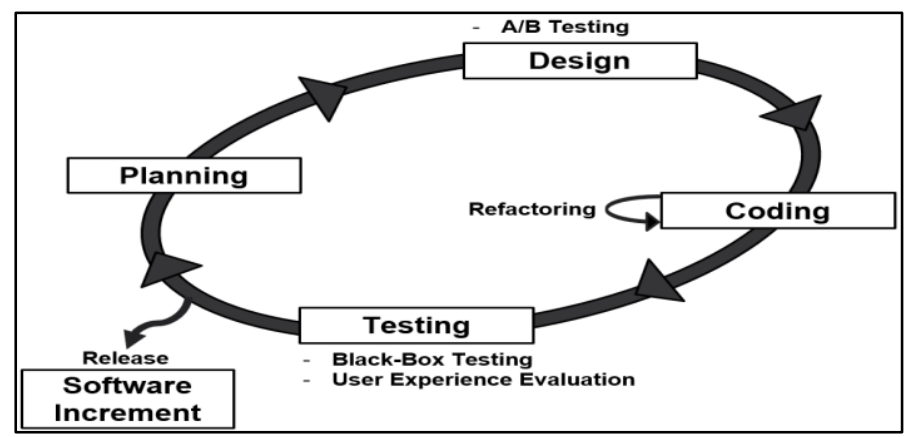

Figure 1. XP Development Method

Based on figure 1, the XP development paradigm includes a set of rules and practices that occur in the context of a four-activity framework: Planning, Design, Coding, and Testing. At the Design stage, there are sub-stages, namely A/B Testing. According Syahidi, Tolle, Supianto, \& Hirashima (2019) who examined the selection of user interface designs using the A/B Testing Method, where two designs were submitted to prospective end users. This will result in the user interface design that the end-user expects.

The research of Syahidi, Subandi, \& Mohamed (2020) and Syahidi, Subandi, Azura, \& Hastuti (2021) states that the character of the XP development method is agile and sensitive to all changes in user needs. In the Coding section, there are Refactoring sub-stages, namely improving the program code structure and errors. In practice, at the final stage, there will be a sub-stage in the form of software increments, where all changes that occur can be handled and present certain feature additions if there are deficiencies in the software. XP also has the nature of accelerating the release of the software, although there are still errors and will be fixed at the sub-stage of the software increment.

The tracking method used in this study is Marker-Based Tracking. According to Syahidi, Tolle, Supianto, \& Arai (2019) Marker-based Tracking is a special marker that is formed like a barcode or black frame, QR code, and printed markers. With the condition as long as it still has a pattern that allows it to be read by a computer, either via a webcam or a camera connected to the computer. Although there are no standard rules about this marker pattern. However, QR codes are the most commonly used markers because they are easy to recognize and do not require much effort to read them. The working concept of Marker-based Tracking is that when using a camera and pointing it at a visual marker such as a $\mathrm{QR}$ or $2 \mathrm{D}$ object that has been set in the database, it will produce output according to what has been programmed (generating 3D objects and their accessories). 
The functional testing method in this study uses the Black-Box Testing method. According to Syahidi, Tolle, Supianto, Hirashima, \& Arai (2020), the meaning of functional is the need for which processes or services must be provided by the application, including how the application must react and take action on certain inputs and how the application behaves in certain situations. This functional requirement is highly dependent on the type of software, the user, and the type of application in which the software is used. Functional requirements can be searched from the question: What should the application do?. Because in essence, the functional requirements must be able to describe the services that can be provided by the application to end users in detail.

The Black-Box Testing method is based on what functions or behaviors the software must perform (Ostrand, 2002). According to research by Syahidi, Supianto, \& Tolle (2019), Black-Box Testing aims to find out what functions the software can perform and to meet user needs and errors that occur in software features. Furthermore, it can define the suitability of the operation of the features of the software. The assessment technique for Black-Box Testing adopts Nidhra \& Dondeti (2012) and Murnane \& Reed (2001) which make a specification table of the requirements of the software features that are built.

The non-functional testing method in this study uses the User Experience (UX) method. According to Syahidi, Tolle, Supianto, Hirashima, \& Arai (2020), the meaning of nonfunctional refers to the need that focuses on the behavioural properties of the application and determines how the system in the application should run as it should. Non-functional requirements place limitations on the application being developed, the development process, and determine the external constraints that the application must meet.

The UX method is used to assess user experience when interacting with software (website, desktop, or mobile-based) (Syahidi, Subandi, \& Mohamed, 2020). The purpose of UX is to provide an element of interest and pleasure when using software (Santoso, Schrepp, Isal, Utomo, \& Priyogi, 2016). To test UX on the Mobile Augmented Reality application, use the User Experience Questionnaire (UEQ) which adopts the research of Santoso, Schrepp, Isal, Utomo, \& Priyogi (2016) states UEQ is an easy and efficient tool or questionnaire to measure UX. UEQ can make it easier to measure UX in a software design. UEQ contains six rating scales, namely: 1). Attractiveness = Does the user like or dislike the software? 2). Perspicuity = Is it easy to get to know the software? Is it easy to learn how to use the software? 3). Efficiency $=$ Can users complete their tasks without simple effort? 4). Dependability = Does the user feel in control of the interaction? 5). Stimulation = Is it interesting and motivating to use the software? 6). Novelty = Is the software innovative and creative? Does the software capture user interest? UEQ has 26 question components and seven answer choices using a positive and negative Likert scale.

\section{RESULT AND DISCUSSIONS \\ Result \\ Planning Stages}

The planning stage will usually begin by describing what system activities are required by business needs, user needs, and system requirements. The things that will be done at this stage are as follows:

1. Observation: the first stage will contain direct observation of POLIBAN, both in terms of buildings and rooms that will be used as objects and information. Consultations with admissions of new students were also carried out to coordinate the visualization of brochures and information content.

2. Study of literature: researchers conduct searches of similar studies, theoretical basis, application development mechanisms, and so on from various scientific sources. 
3. Requirements analysis: there are two needs to be analyzed, namely user needs and software requirements. Belonging to user needs, users can view the information in the form of 3D objects from POLIBAN along with the rooms in it and other information in the form of audio and text. Users can rotate or view objects and adjust the scale, users can access the AR start menu, users can access the about us menu, users can access the menu on how to use the application, and users can exit the application in full. Meanwhile, the software needs are Corel Draw X7, Photoshop CS6, Blender, Unity 3D, Vuforia, Android SDK, and JDK.

\section{Design Stages}

This stage consists of designing the system and the user interface of the application. Figure 2 is a use case diagram design. Use case diagrams to describe a group of use cases and actors accompanied by relationships between them. This use case diagram describes and explains the behavior desired by the user as an actor. In this application the user can perform behaviours, namely selecting menus such as Start AR, How to Use, About, and Exit (See Figure 2). Furthermore, there is the Use Case Realization which is presented in table 1.

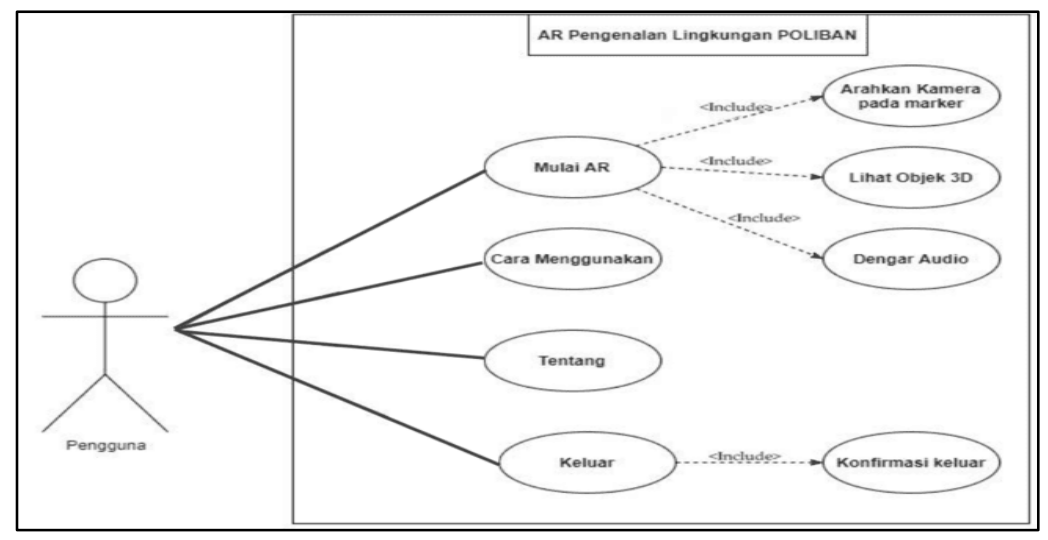

Figure 2. Use Case Diagram

The next design is to design a user interface based on research on user needs, by adapting the A/B Testing method from the research of Syahidi, Tolle, Supianto, \& Hirashima (2019). The A/B Testing method is used to determine and choose what kind of user interface design is recommended by prospective end-users. The result of selecting the user interface design using A/B Testing is design $\mathrm{B}$ with a percentage of $90 \%$ of respondents (potential end users) recommending it on the grounds that in general the design is quite simple and will be able to provide appropriate interaction and visualization. The results of design A form the user interface design which is presented in the form of a wireframe can be seen in Figure 3.

The marker design is needed to later be used as a means of generating 3D objects from the AR application. The marker design is in the form of a brochure that has been designed by the committee for new admissions, the marker design can be seen in Figure 4. The marker is a color image target from the brochure.

\section{Coding Stages}

In order for the application to run, the design that was made earlier will be designed in a programming language with a coding process. This stage is an implementation of designing a system model that has been made into program code that produces a prototype of the software. The application that will be used at this stage is Unity 3D, which will organize and combine all designs in Unity 3D, enter markers that have been registered in the Vuforia database so that the markers can be read by a machine, and generate the expected 3D object if it is detected successfully based on the target pattern. The results of coding by producing an application with a suitable user interface, implementing the application can be seen in Figure 5. 
Table 1. Use Case Realization

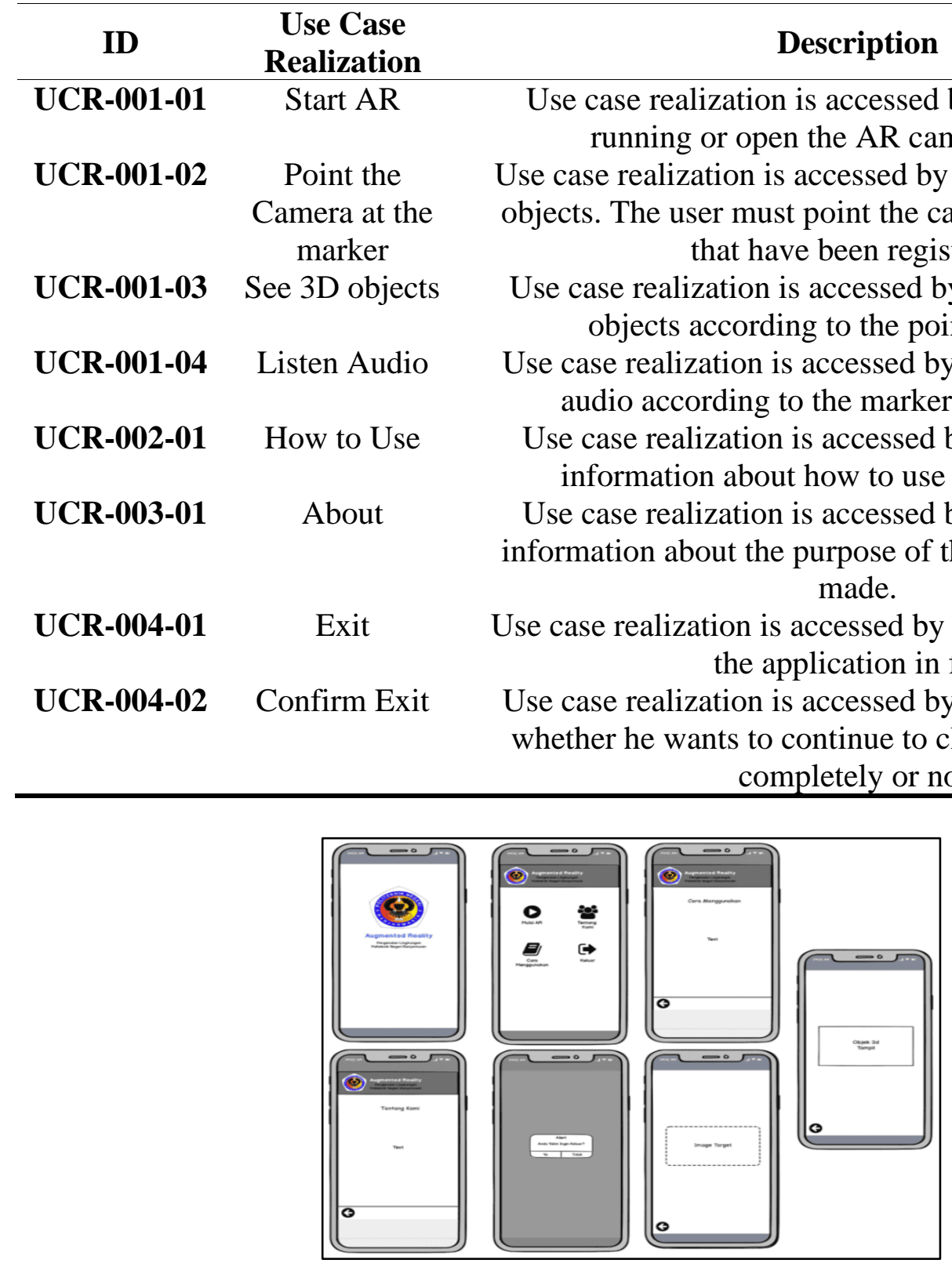

Figure 3. User Interface Design

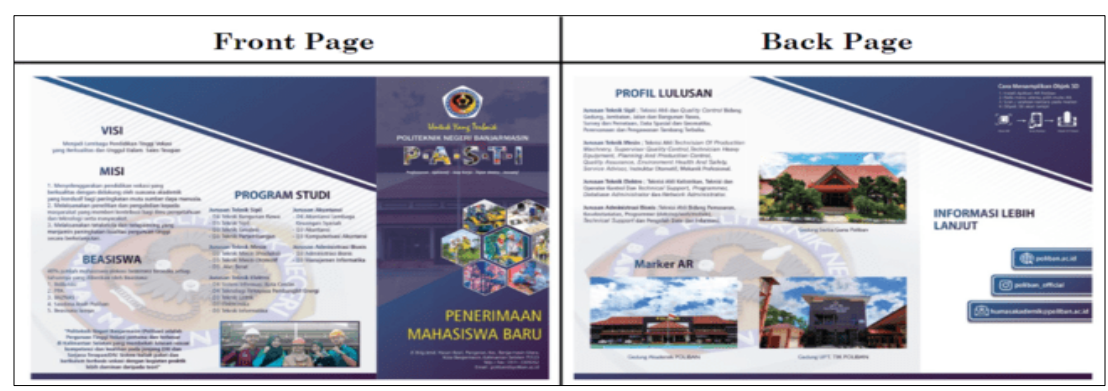

Figure 4. Marker Design

\section{Testing Stages}

This stage is a testing phase for applications that have been built, at this stage it is determined by the system user and focuses on the features and functionality of the entire system then reviewed by the system user in case of errors or other functions that do not work as they should. Testing is usually carried out by several examiners to be asked for their comments, 
criticisms, and suggestions. After the test results come out, a re-evaluation will be carried out if there are deficiencies in the application and require repair. Then it will be entered into the software increment sub-stage. The results of functional testing using the Black-Box Testing method are presented in table 2 .

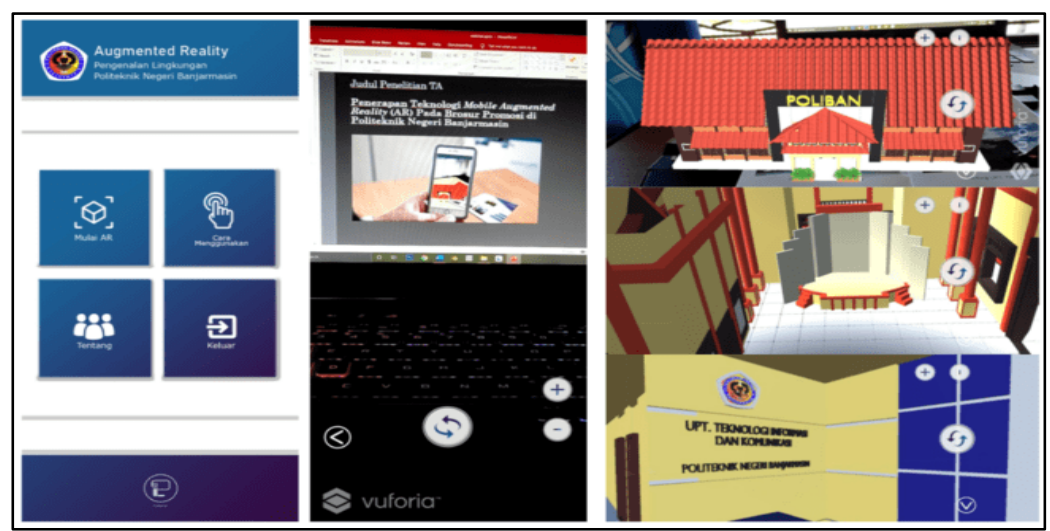

Figure 5. System Implementation

Table 2. Black-Box Testing Results

\begin{tabular}{|c|c|c|c|}
\hline ID & Features & Expected Results & Test Results \\
\hline ARPol-1 & Application Icon & $\begin{array}{l}\text { Before entering the application, the user } \\
\text { can see the application icon/logo. }\end{array}$ & Successfully \\
\hline ARPol-2 & Splash Screen & $\begin{array}{l}\text { Before entering the main menu, the user } \\
\text { will see a splash screen for } 5 \text { seconds } \\
\text { equipped with SFX. }\end{array}$ & Successfully \\
\hline ARPol-3 & Main Menu & Users can access the main menu. & Successfully \\
\hline ARPol-4 & Camera AR Page & $\begin{array}{l}\text { Users can access marker detection on the } \\
\text { brochure and see 3D objects that are } \\
\text { generated according to the pattern } \\
\text { detection on the marker. }\end{array}$ & Successfully \\
\hline ARPol-5 & AR Start Button & $\begin{array}{l}\text { Users can access the AR Start button and } \\
\text { enter the AR camera page. }\end{array}$ & Successfully \\
\hline ARPol-6 & $\begin{array}{l}\text { Button How To } \\
\text { Use }\end{array}$ & $\begin{array}{l}\text { Users can access the How to use button } \\
\text { and open a page that shows how to use the } \\
\text { application. }\end{array}$ & Successfully \\
\hline ARPol-7 & About Button & $\begin{array}{l}\text { Users can access the About button and } \\
\text { open a page that contains the purpose of } \\
\text { the application being made. }\end{array}$ & Successfully \\
\hline ARPol-8 & Exit Button & $\begin{array}{l}\text { The user can access the exit button so that } \\
\text { they can fully exit the application. }\end{array}$ & Successfully \\
\hline ARPol-9 & Back Button & $\begin{array}{l}\text { Users can access the back button to go to } \\
\text { the main page. }\end{array}$ & Successfully \\
\hline ARPol-10 & $\begin{array}{l}\text { Zoom In/Out } \\
\text { Button }\end{array}$ & $\begin{array}{l}\text { Users can access the Zoom In/Out button } \\
\text { so that } 3 \mathrm{D} \text { objects can be enlarged as well } \\
\text { as reduced. }\end{array}$ & Successfully \\
\hline ARPol-11 & Rotate Button & $\begin{array}{l}\text { Users can access the Rotate button so that } \\
\text { 3D objects can be rotated. }\end{array}$ & Successfully \\
\hline
\end{tabular}


The results of non-functional testing using UEQ are presented in Table 3. As many as 50 respondents, namely prospective new students, were included to assess the user experience of the application. The benchmark graph of the assessment using UEQ can be seen in Figure 6 .

Table 3. UEQ Results

\begin{tabular}{|c|c|c|c|}
\hline ID & Aspect & Questions & $\begin{array}{l}\text { Average } \\
\text { Answer } \\
\text { Results }\end{array}$ \\
\hline UEQ-1 & Attractiveness & Do users like the AR POLIBAN application? & 3.00 \\
\hline UEQ-2 & Perspicuity & $\begin{array}{l}\text { How easy is it to get to know the AR POLIBAN } \\
\text { application? How easy is it to operate the AR } \\
\text { POLIBAN app? }\end{array}$ & 2.99 \\
\hline UEQ-3 & Efficiency & $\begin{array}{l}\text { Can users use the AR POLIBAN application as a } \\
\text { media for promotion and introduction to the } \\
\text { POLIBAN building? }\end{array}$ & 3.00 \\
\hline UEQ-4 & Dependability & $\begin{array}{l}\text { Can users interact with the AR POLIBAN } \\
\text { application properly? }\end{array}$ & 2.53 \\
\hline UEQ-5 & Stimulation & $\begin{array}{l}\text { Is the interface and visualization of the AR } \\
\text { POLIBAN application attractive? Can it motivate } \\
\text { users to use the AR POLIBAN application as a } \\
\text { media application for promotion and introduction } \\
\text { to the POLIBAN building? }\end{array}$ & 3.00 \\
\hline \multirow[t]{2}{*}{ UEQ-6 } & Novelty & $\begin{array}{l}\text { Has the AR POLIBAN application been } \\
\text { innovative and creative? }\end{array}$ & 2.72 \\
\hline & & UX average value & 2.87 \\
\hline
\end{tabular}

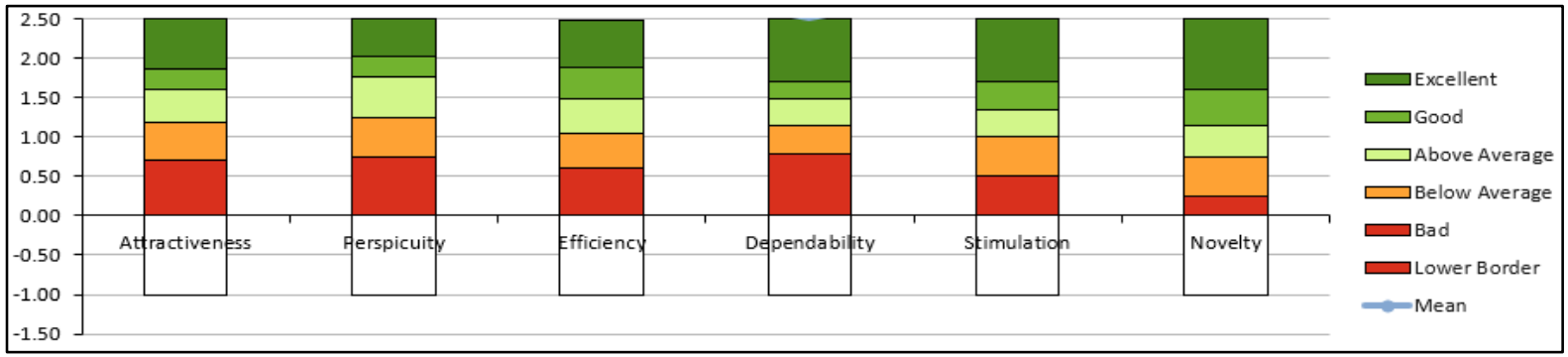

Figure 6. Benchmark Graph of UEQ Results

\section{Software Increment}

Based on the results of the Black-Box Testing (see table 2), there were no features that did not run successfully. However, there were several suggestions for improvements/additions for future applications, namely more detailing the rooms in each building, adding information from POLIBAN leaders (including department heads, study program heads, laboratory heads, and unit heads), and developing them into Virtual Reality (VR) application with the use of additional hardware.

\section{Discussions}

Based on the results of the Black-Box Testing that have been presented in table 2, it can be concluded that all the features of the application can function as expected. This test has been carried out by involving 10 testers and paying attention to each specification of the requirements of the application features. The results of the UEQ test (See Table 3) are that the highest score is in the aspects of Attractiveness, Efficiency, and Stimulation with a value of 
3.00 with the predicate excellent. Then the lowest score is in the Dependability aspect with a score of 2.53 with the predicate excellent, which means that this aspect needs to be improved in terms of application interaction with users. The overall average value of the user experience test with UEQ is 2.87 with the predicate excellent and it can be ascertained that the elements of the user experience aspects have been fulfilled very well by the AR POLIBAN application. Furthermore, based on the results of the benchmark graph (See Figure 6) it was obtained that the total score for the excellent predicate (dark green) was very dominant with a total score of 4.2 with the translation $($ Attractiveness $=0.64)+($ Perspicuity $=0.47)+($ Efficiency $=0.6)+$ $($ Dependability $=0.8)+($ Stimulation $=0.8)+($ Novelty $=0.89)$.

From the results of the user experience assessment, the opinions of users were also explored, where they also felt happy and enjoyed the application and had an impact on the interest of prospective students to choose and continue their studies at POLIBAN. However, it is necessary to increase the detailed information presented by the application and also other supporting features.

\section{CONCLUSIONS}

The application of Mobile Augmented Reality in the POLIBAN promotional brochure can realize the virtual world into the real world, can display 2D image objects into 3D objects accompanied by other supporting information in the form of audio and additional text, which is by the results of functional testing and can be accessed via mobile applications. Through the media with Mobile Augmented Reality Technology, information that has not been included in the brochure can be displayed virtually without additional brochures. Based on functional testing with an evaluation of the user experience, the resulting average value is 2.87 with an excellent predicate and it can be stated that the application made has met the very good aspects of the user experience. Furthermore, the presence of Mobile Augmented Reality-based brochures can have an impact on saving raw materials in making more brochures and costs can also be done and can attract new POLIBAN student candidates. Further research can be recommended in the form of detailing the rooms in each building, information from POLIBAN leaders, increasing interaction, and further development using Virtual Reality (VR) and even Mixed/Extended Reality (MR/XR) Technology.

\section{REFERENCES}

Afendi, A., Gustia, I., \& Maleha, N. Y. (2021). Pengaruh Virus Corona (Covid-19) Terhadap Penerimaan Mahasiswa Baru di Universitas Indo Global Mandiri. Jurnal Ilmiah Mahasiswa Ekonomi Syariah, 1(1), 75-82.

Azuma, R. T. (1997). A Survey of Augmented Reality. In Presence: Teleoperators and Virtual Environments 6, 4(1997), 355-385.

Hermawan, L., \& Hariadi, M. (2015). Pemanfaatan Augmented Reality sebagai Media Informasi Kampus Menggunakan Brosur. Seminar Nasional Teknologi Informasi Dan Komunikasi (SENTIKA), Sentika, 81-88.

Indrawati, B. (2020). Tantangan dan Peluang Pendidikan Tinggi Dalam Masa dan Pasca Pandemi Covid-19. Jurnal Kajian Ilmiah, 1(1), 39-48.

Kato, H., \& Billinghurst, M. (1999). Marker Tracking and HMD Calibration for a Video-Based Augmented Reality Conferencing System. Proceedings of The 2nd IEEE and ACM International Workshop on Augmented Reality (IWAR), 85-94.

MedIndo. (2020). Pengaruh Korona di Pendidikan Tinggi. Media Indonesia, 1-6.

Murnane, T., \& Reed, K. (2001). On the Effectiveness of Mutation Analysis as a Black Box Testing Technique. Proceedings of The Australian Software Engineering Conference (ASWEC), 12-20.

Nadira, Z., Sujaini, H., \& Pratiwi, H. S. (2016). Implementasi Augmented Reality pada Brosur 
Teknik Informatika Universitas Tanjungpura menggunakan Metode Marker. Jurnal Sistem Dan Teknologi Informasi (JUSTIN), 1(1), 1-6.

Nidhra, S., \& Dondeti, J. (2012). Black Box and White Box Testing Techniques - A Literature Review. International Journal of Embedded Systems and Applications (IJESA), 2(2), 2950. https://doi.org/10.5121/ijesa.2012.2204

Ostrand, T. (2002). Black-Box Testing - in Book Encyclopedia of Software Engineering. United States: Wiley.

Pressman, R. S. (2010). Software Engineering: A Practitioner's Approach. McGraw-Hill Education.

Rachmanto, A. D., \& Noval, M. S. (2018). Implementasi Augmented Reality sebagai Media Pengenalan Promosi Universitas Nurtanio Bandung menggunakan Unity 3D. Jurnal Teknologi Informasi Dan Komunikasi, 9(1), 29-37.

Santoso, H. B., Schrepp, M., Isal, R. Y. K., Utomo, A. Y., \& Priyogi, B. (2016). Measuring User Experience of the Student-Centered e-Learning Environment. The Journal of Educators Online (JEO), 13(1), 58-79.

Subandi, Joniriadi, Syahidi, A. A., \& Mohamed, A. (2020). Mobile Augmented Reality Application with Multi-Interaction for Learning Solutions on the Topic of Computer Network Devices (Effectiveness, Interface, and Experience Design). Proceedings of The 3rd International Conference on Vocational Education and Electrical Engineering (ICVEE), 4-10.

Suryadi, D. (2011). Promosi Efektif. Jakarta: PT. Suka Buku.

Syahidi, A. A., Subandi, Azura, A. N., \& Hastuti, I. (2021). Virtual Museum Tour in Wasaka Banjarmasin to Introduce the Collection of Leaders and Local Heroes Based on Mobile Augmented Reality Technology in the New Normal Era. COMPILER Journal, 10(1), 110.

Syahidi, A. A., Subandi, \& Mohamed, A. (2020). AUTOC-AR: A Car Design and Specification as a Work Safety Guide Based on Augmented Reality Technology. Jurnal Pendidikan Teknologi Dan Kejuruan, 26(1), 18-25.

Syahidi, A. A., Supianto, A. A., \& Tolle, H. (2019). Design and Implementation of Bekantan Educational Game ( BEG) as a Banjar Language Learning Media. International Journal of Interactive Mobile Technologies (IJIM), 13(03), 108-124. https://doi.org/10.3991/ijim.v13i03.9257

Syahidi, A. A., Tolle, H., Supianto, A. A., \& Arai, K. (2018). BandoAR: Real-Time Text Based Detection System Using Augmented Reality for Media Translator Banjar Language to Indonesian with Smartphone. 2018 IEEE 5th International Conference on Engineering Technologies and Applied Sciences (ICETAS), 1-6. https://doi.org/10.1109/ICETAS.2018.8629251

Syahidi, A. A., Tolle, H., Supianto, A. A., \& Hirashima, T. (2019). Educational Media Design for Learning Basic Programming in Branching Control Structure Material Using ProblemPosing Learning Model. Kinetik: Game Technology, Information System, Computer Network, Computing, Electronics, and Control Journal, 4(4), 325-336.

Syahidi, A. A., Tolle, H., Supianto, A. A., Hirashima, T., \& Arai, K. (2020). Interactive MLearning Media Technology to Enhance the Learning Process of Basic Logic Gate Topics in Vocational School and Engineering Education. International Journal of Engineering Education (IJEE), 2(2), 50-63. 